\title{
Low-temperature growth and whole-cell kinetics of a marine ammonium oxidizer*
}

\author{
Ronald D. Jones and Richard Y. Morita
}

Department of Microbiology and School of Oceanography, Oregon State University, Corvallis, Oregon 97331-3804, USA

\begin{abstract}
An ammonium oxidizing bacterium has been isolated from Alaskan waters that is capable of growth at $-5^{\circ} \mathrm{C}$. Significant differences in the cardinal growth temperatures and ammonium oxidation rates were observed using cells grown at 5 and $25^{\circ} \mathrm{C}$ in chemostat culture. Cells grown at $5^{\circ} \mathrm{C}$ had an optimum growth temperature of $22^{\circ} \mathrm{C}$ and a maximum of approximately $29^{\circ} \mathrm{C}$. Cells grown at $25^{\circ} \mathrm{C}$ had an optimum growth temperature of $30^{\circ} \mathrm{C}$ and a maximum of approximately $38^{\circ} \mathrm{C}$. Whole-cell kinetic studies failed to define the substrate of the enzyme system as either $\mathrm{NH}_{3}$ or $\mathrm{NH}_{4}^{+}$, but did indicate that there are physiological differences between cells of this ammonium oxidizer when grown at 5 and $25^{\circ} \mathrm{C}$. The data strongly suggest that temperatures close to the environmental temperatures should be used and that adaptation to higher temperatures should be avoided in autoecological studies.
\end{abstract}

\section{INTRODUCTION}

Although measurements of inorganic nitrogen species have indicated that nitrification takes place in cold ocean waters $\left(<5^{\circ} \mathrm{C}\right)$, no nitrifiers have been isolated that will grow well below $5^{\circ} \mathrm{C}$. Carlucci \& Strickland (1968) found that none of their isolates from the northern Pacific Ocean would grow or oxidize ammonium at $5^{\circ} \mathrm{C}$, even after several months. In addition to this, the optimum growth temperatures for nitrifiers usually fall within the range of 25 to $35^{\circ} \mathrm{C}$. Despite these findings, Horrigan (1981) has recently presented indirect evidence that nitrification is occurring under the Ross Ice Shelf, Antartica, at temperatures below $-2{ }^{\circ} \mathrm{C}$, and Heneriksen et al. (1981) have directly measured nitrification in Danish sediments at $5^{\circ} \mathrm{C}$. The vast majority of oceanic waters are $5^{\circ} \mathrm{C}$ or colder, yet we know little about the organisms responsible for nitrification at these temperatures.

Temperature is one of the major environmental factors affecting the growth and metabolic activities of marine microorganisms. It is well known that diatoms, dinoflagellates and bacteria grow best in the laboratory at temperatures 10 to $20^{\circ} \mathrm{C}$ higher than their natural habitat (Braarud, 1937; ZoBell, 1946). This fact should not be neglected in the study of the various physiological processes catalyzed by the marine bacteria. Furth-

- Published as Technical Paper No. 7325, Oregon Agricultural Experiment Station ermore, it is known that there are physiological differences between cells grown at environmental and optimal laboratory temperatures (Frank 1962, Haight and Morita 1966). Differences in fermentation by a facultative psychrophile at different temperatures were noted by Upadhyay and Stokes (1962). These and other studies indicate that some of the differences observed between laboratory cultures and microorganisms in the environment may be entirely due to temperature effects.

An ammonium oxidizer has been isolated in our laboratory which will actively oxidize ammonium and grow at $-5^{\circ} \mathrm{C}$. This paper addresses the temperature characteristics and whole cell kinetics of this organism.

\section{MATERIALS AND METHODS}

Organism and cultural methods. The marine ammonium oxidizing bacterium, tentatively called Nitrosomonas sp. 4W30, was isolated from Alaskan coastal waters $\left(11^{\circ} \mathrm{C}\right)$. Initial enrichments and final purification procedures (Jones and Hood, 1980) were performed at $10^{\circ} \mathrm{C}$. The pure culture was initially incubated at $10^{\circ} \mathrm{C}$ with subsequent incubations at 15,20 and $25^{\circ} \mathrm{C}$. Stock cultures of the organism have been maintained with bi-weekly transfers into fresh medium at $25^{\circ} \mathrm{C}$ for $3 \mathrm{yr}$. Portions of these stock cultures were used as inocula for the chemostat cultures used in these experiments. 
Cells used in the assays were grown in two identical $500 \mathrm{ml}$ chemostats equipped with automatic pH controllers which maintained the $\mathrm{pH}$ at $7.8 \pm 0.05$ by the addition of sterile $5 \% \mathrm{~K}_{2} \mathrm{CO}_{3}$. The medium used was the same as that described by Jones and Hood (1980) with the salinity adjusted to $30 \%$ using Instant Ocean Synthetic Sea Salts (Aquarium Systems, Inc.). Cultures were vigorously aerated and agitated by a magnetic stirring bar. Generation times were controlled by the speed of addition of fresh medium, such that cells with either 90 or $150 \mathrm{~h}$ generation times were used in the experiments. The chemostats were maintained at either 5 or $25^{\circ} \mathrm{C}$. Cells grown at $5^{\circ} \mathrm{C}$ were gradually adapted to this temperature by first growing them at $25^{\circ} \mathrm{C}$ and then stepping the temperature down in $5 \mathrm{C}^{\circ}$ increments at $2 \mathrm{~d}$ intervals until a final temperature of $5^{\circ} \mathrm{C}$ was achieved. It was found that this process was necessary to obtain cells in a reasonable period of time as initial growth of $25^{\circ} \mathrm{C}$ cells at $5^{\circ} \mathrm{C}$ was extremely slow. Once populations in the chemostats had been established ( 3 to 5 generations) $100 \mathrm{ml}$ of the culture was removed and filtered onto a sterile $0.45 \mu \mathrm{m}$ membrane filter (Millipore Corp.), washed twice with sterile $\mathrm{NH}_{4}^{+}$free medium and resuspended in $10 \mathrm{ml}$ of the same medium. Care was taken to ensure that $5^{\circ} \mathrm{C}$ cells were not subjected to elevated temperatures in the concentration process by the use of pre-cooled media and equipment. These suspensions were subjected to Petroff-Hauser direct counts and 0.1 or $0.2 \mathrm{ml}$ portions were used as an inoculum.

Temperature effects on ammonium oxidation. Ammonium oxidation rates (nitrite formation) as a function of temperature were determined with a temperature gradient incubator (Scientific Industries). The temperature gradient incubator was adjusted so that 25 different temperatures, at 1 to $3 \mathrm{C}^{\circ}$ intervals were obtained. Temperatures ranged from -5 to $39^{\circ} \mathrm{C}$ for the $5^{\circ} \mathrm{C}$ acclimated cells, and from 4 to $51^{\circ} \mathrm{C}$ for the $25^{\circ} \mathrm{C}$ acclimated cells. The incubator tubes contained $20 \mathrm{ml}$ of sterile ammonium oxidizer medium supplemented with $0.02 \mathrm{M} \mathrm{N}$-2-hydroxyethylpiperazine$\mathrm{N}^{\prime}$-2-ethane sulfonic acid (HEPES), $\mathrm{pH} 7.8$ and $100 \mathrm{mg}$ $1^{-1} \mathrm{NH}_{4}^{+}-\mathrm{N}$ as $\left(\mathrm{NH}_{4}\right)_{2} \mathrm{SO}_{4}$. Tubes were temperature equilibrated for $12 \mathrm{~h}$ before inoculation with $0.2 \mathrm{ml}$ of the previously described inoculum. Cells with $90 \mathrm{~h}$ generation times were used for these experiments. Nitrite production from $\mathrm{NH}_{4}^{+}$was used as an indicator of growth. Samples $(5.0 \mathrm{ml})$ were taken at 10 and $24 \mathrm{~h}$ and analyzed for $\mathrm{NO}_{2}^{-}$by the method described by Bendschneider and Robinson (1952). Experiments were duplicated and $\mathrm{NO}_{2}^{-}$assays were performed in triplicate. Ammonium oxidation rates were determined by subtracting the $10 \mathrm{~h} \mathrm{NO}_{2}^{-}$concentrations from the $24 \mathrm{~h}$ concentrations and calculating the oxidation rate for the intervening time, thus eliminating initial nitrite production by stressed cells. Oxidation rates were normalized to mmoles $\mathrm{I}^{-1} \mathrm{~h}^{-1}$ at a cell density of $10^{6} \mathrm{ml}^{-1}$, using the Petroff-Hauser direct counts of the inoculum and assuming a linear relationship between cell number and activity.

Temperature and $\mathrm{pH}$ effects on whole cell kinetics. Since both increasing temperature and $\mathrm{pH}$ produce an increase in $\mathrm{NH}_{3}$ concentration it has been suggested that $\mathrm{NH}_{3}$ rather than $\mathrm{NH}_{4}^{+}$may be the actual substrate of the ammonium oxidizers (Suzuki et al., 1974). The effects of these 2 parameters on whole cell kinetics were examined.

Temperature effects were examined with respect to both 5 and $25^{\circ} \mathrm{C}$ acclimated cells while $\mathrm{pH}$ effects were only determined using $5^{\circ} \mathrm{C}$ acclimated cells. To determine the effects of temperature on the $\mathrm{Km}$ and $\mathrm{V} \max$ values of whole cells, a series of $60 \mathrm{ml}$ serum bottles containing $\mathrm{pH} 7.8$ HEPES buffered medium with 12 different $\mathrm{NH}_{4}^{+}-\mathrm{N}$ concentrations $(0,0.05,0.1,0.3,0.5$, $\left.0.7,1.0,3.0,5.0,7.0,10.0,20.0 \mathrm{mg} \mathrm{l}^{-1} \mathrm{NH}_{4}^{+} \mathrm{N}\right)$ was prepared. In all cases the $\mathrm{pH}$ was temperature corrected. These bottles were capped with neoprene stoppers to exclude atmospheric $\mathrm{NH}_{3}$ exchange and were temperature equilibrated for $12 \mathrm{~h}$ before being inoculated. Bottles received $0.1 \mathrm{ml}$ of the inoculum prepared from 5 or $25^{\circ} \mathrm{C}$ grown cells with $150 \mathrm{~h}$ generation times. The bottles were incubated at the appropriate temperature for $6 \mathrm{~h}$ on a rotary shaker at $100 \mathrm{rpm}$ and then assayed at 5 and $20^{\circ} \mathrm{C}$ while $25^{\circ} \mathrm{C}$ grown cells were assayed at 5,20 , and $25^{\circ} \mathrm{C}$. Bottles were prepared in triplicate and experiments at each temperature were duplicated. Values were averaged and analyzed using Lineweaver-Burk plots to determine $\mathrm{Km}$ and $\mathrm{Vmax}_{\max }$ values.

The effect of $\mathrm{pH}$ on the $\mathrm{Km}$ and Vmax values of $5^{\circ} \mathrm{C}$ acclimated cells was determined by incubation of $\mathrm{NH}_{4}^{+}-\mathrm{N}$ concentration series bottles with 3 different $\mathrm{pH}$ values $\left(6.8,7.4\right.$, and 7.8 ) at $5^{\circ} \mathrm{C}$ for $6 \mathrm{~h}$. Nitrite was assayed and the data was analyzed as before. With both, the temperature and $\mathrm{pH}$ series incubation times were sufficiently short $(6 \mathrm{~h})$ so as not to affect $\mathrm{NH}_{4}^{+}-\mathrm{N}$ concentrations in the assay bottles significantly ( $<15 \%$ change in $\mathrm{NH}_{4}^{+}-\mathrm{N}$ concentrations).

\section{RESULTS}

The results of the temperature gradient experiments are shown in Fig. 1. Both the 5 and $25^{\circ} \mathrm{C}$ cells were able to oxidize ammonium over a wide range of temperatures. There was, however, a significant downward shift in the minimum, optimum and maximum growth temperatures for the cells grown at $5^{\circ} \mathrm{C}$. While the $5^{\circ} \mathrm{C}$ adapted cells grew at temperatures as low as $-5^{\circ} \mathrm{C}$, had an optimum of $22^{\circ} \mathrm{C}$ and a maximum near $29^{\circ} \mathrm{C}$, 


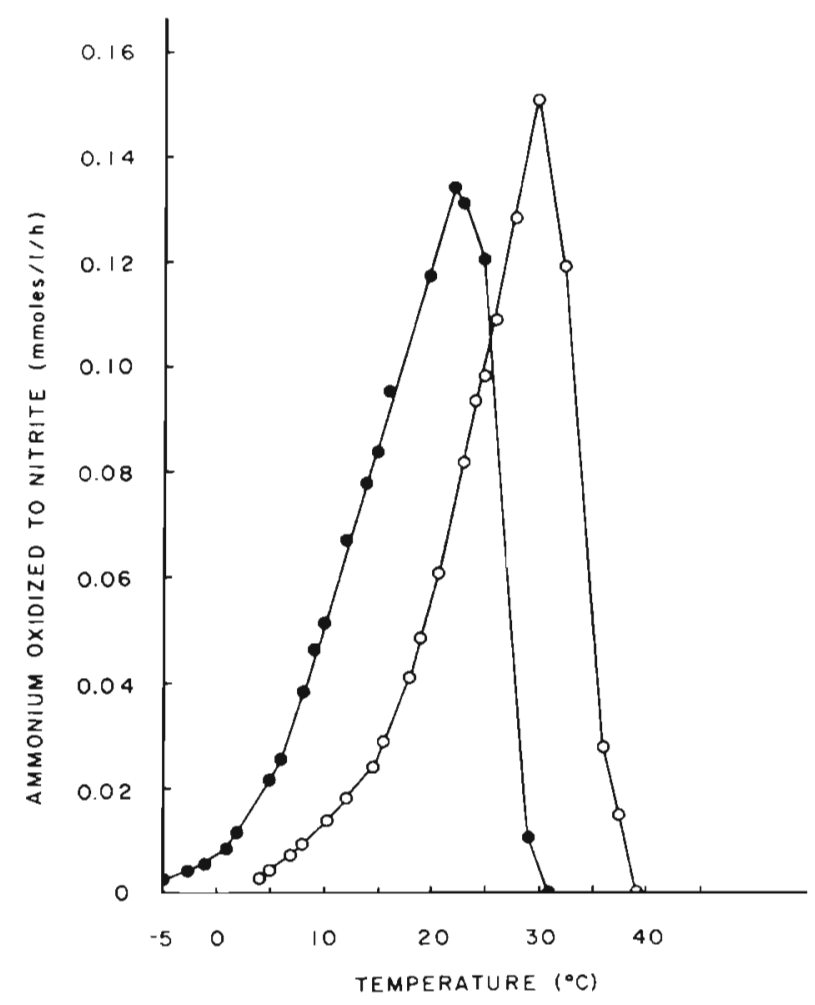

Fig. 1. Effects of temperature on ammonium oxidation by Nitrosomonas sp. $4 \mathrm{~W} 30$ grown at 25 and $5^{\circ} \mathrm{C}$. Oxidation rate is expressed as mmoles $1^{-1} \mathrm{~h}^{-1}$ at a cell density of $10^{6} \mathrm{ml}^{-1}$. $025^{\circ} \mathrm{C}$ grown cells, $\bullet 5^{\circ} \mathrm{C}$ grown cells

cells grown at $25^{\circ} \mathrm{C}$ did not grow well below $4{ }^{\circ} \mathrm{C}$, had an optimum temperature of $30^{\circ} \mathrm{C}$ and a maximum growth temperature just above $38^{\circ} \mathrm{C}$. Cells grown at $5^{\circ} \mathrm{C}$ will not grow at any temperature after being exposed to $30^{\circ} \mathrm{C}$ for $30 \mathrm{~min}$. The $5^{\circ} \mathrm{C}$ adapted cells oxidized significantly more $\mathrm{NH}_{4}^{+}$at lower temperatures $\left(<25^{\circ} \mathrm{C}\right)$ than did the $25^{\circ} \mathrm{C}$ grown cells. For example, at an incubation temperature of $5^{\circ} \mathrm{C}$, cells grown at $25^{\circ} \mathrm{C}$ oxidize 0.0043 mmoles $1^{-1} \mathrm{~h}^{-1}$ at $10^{6}$ cells $\mathrm{ml}^{-1}$ while cells grown at $5^{\circ} \mathrm{C}$ oxidize 0.0219 mmoles $1^{-1}$ $\mathrm{h}^{-1}$ at $10^{6}$ cells $\mathrm{ml}^{-1}$, a 5.1 fold increase in activity. Nitrite production drops 35 times from 30 (optimum growth temperature) to $5^{\circ} \mathrm{C}$ for $25^{\circ} \mathrm{C}$ grown cells while only a 6 -fold drop in activity from 22 to $5^{\circ} \mathrm{C}$ was observed for $5^{\circ} \mathrm{C}$ grown cells.

The effects of incubation temperature on whole cell kinetics of 5 and $25^{\circ} \mathrm{C}$ grown cells are shown in Table 1 Both 5 and $25^{\circ} \mathrm{C}$ cells gave decreasing $\mathrm{Km}$ for both $\mathrm{NH}_{3}+\mathrm{NH}_{4}^{+}$and $\mathrm{NH}_{3}$ with decreasing temperature. Vmax values also decreased with decreasing temperature for both cell types. The Vmax and $\mathrm{Km}$ values were significantly higher for the $5^{\circ} \mathrm{C}$ adapted cells than the $25^{\circ} \mathrm{C}$ cells at the temperatures examined.

As shown in Fig. 2, the effect of $\mathrm{pH}$ on $5^{\circ} \mathrm{C}$ adapted cells of Nitrosomonas sp. 4W30 was to increase the slope of the line as $\mathrm{pH}$ decreased, thus giving increasing $\mathrm{Km}$ values with a decrease in $\mathrm{pH}$ (Table 2). Vmax values remained constant as $\mathrm{pH}$ varied. When $\mathrm{Km}$ values were expressed in terms of $\mathrm{NH}_{3}$ rather than $\mathrm{NH}_{3}$ $+\mathrm{NH}_{4}^{+}, \mathrm{Km}$ values decreased with decreasing $\mathrm{pH}$ rather than increasing as before.

\section{DISCUSSION}

Temperature is one of the major factors affecting nitrification in the oceans. The only other factor which may play a larger role in regulating the rates of nitrification may be the availability of substrate. Although recent work by Horrigan (1981) has indicated that nitrifiers are active in cold waters $\left(<-2{ }^{\circ} \mathrm{C}\right)$, until this report no organism capable of ammonium oxidation at these temperatures had been isolated. It seems likely that part of the reason Carlucci and Strickland (1968) did not demonstrate low temperature growth with any isolates may have been due to elevated temperatures during initial handling of the samples and the lack of temperature adaptation of their cultures to lower temperatures. With Nitrosomonas sp. 4 W30 grown at $25^{\circ} \mathrm{C}$.

Table 1 Effects of growth and incubation temperature on the $\mathrm{Km}$ and Vmax of ammonium oxidation by whole cells of Nitrososmonas sp. 4 W30

\begin{tabular}{|c|c|c|c|c|c|}
\hline \multirow[b]{2}{*}{ Incubation temperature: } & \multicolumn{3}{|c|}{ Growth temperature $25^{\circ} \mathrm{C}$} & \multicolumn{2}{|c|}{ Growth temperature $5^{\circ} \mathrm{C}$} \\
\hline & $5^{\circ} \mathrm{C}$ & $20^{\circ} \mathrm{C}$ & $25^{\circ} \mathrm{C}$ & $5^{\circ} \mathrm{C}$ & $20^{\circ} \mathrm{C}$ \\
\hline $\begin{array}{l}\mathrm{Km} \\
(\mathrm{mM})^{\mathrm{a}}\end{array}$ & $.090 \pm .01$ & $182 \pm .02$ & $.250 \pm .04$ & $166 \pm .02$ & $.256 \pm .04$ \\
\hline $\begin{array}{l}\mathrm{Km} \\
(\mathrm{nM})^{\mathrm{b}}\end{array}$ & $593 \pm 65$ & $3625 \pm 398$ & $7167 \pm 1147$ & $1094 \pm 132$ & $5100 \pm 797$ \\
\hline $\begin{array}{l}V \max \\
\left(\operatorname{mmoles} \mathrm{I}^{-1} \mathrm{~h}^{-1}\right)^{\mathrm{c}}\end{array}$ & $.007 \pm .001$ & $.039 \pm .006$ & $.047 \pm .007$ & $.020 \pm .003$ & $.057 \pm .009$ \\
\hline \multicolumn{6}{|c|}{$\begin{array}{l}\text { ¿ Expressed as } \mathrm{NH}_{4}^{+} \text {and } \mathrm{NH}_{3} \text { combined } \\
\text { b Expressed as } \mathrm{NH}_{3} \text { only } \\
\text { c Velocity is expressed at a cell density of } 10^{6} \mathrm{ml}^{-1}\end{array}$} \\
\hline
\end{tabular}




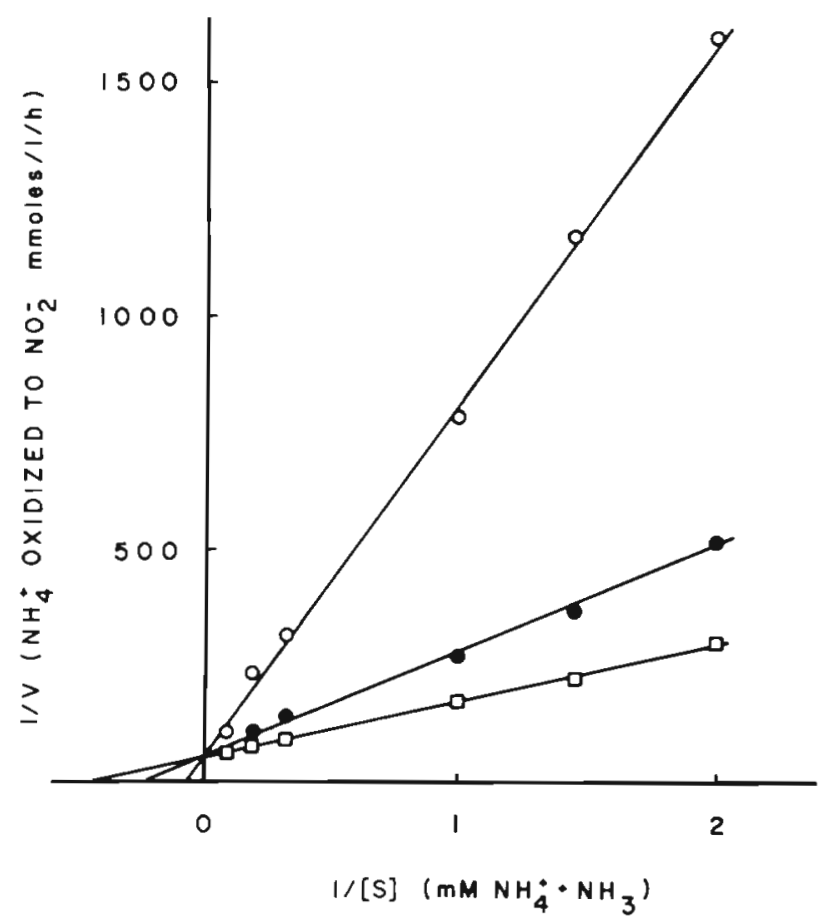

Fig. 2. Effects of $\mathrm{pH}$ and $\mathrm{NH}_{4}^{+}+\mathrm{NH}_{3}$ concentration on substrate oxidation by Nitrosomonas sp. $4 \mathrm{~W} 30$ grown at $5^{\circ} \mathrm{C}$. Velocity expressed as mmoles $\mathrm{l}^{-1} \mathrm{~h}^{-1}$ at a cell density of $10^{6}$ $\mathrm{ml}^{-1} . \circ \mathrm{pH} 6.8, \bullet \mathrm{pH} 7.4, \square \mathrm{pH} 7.8$

Table 2. Effect of $\mathrm{pH}$ on the $\mathrm{Km}$ and $\mathrm{V} \max$ of ammonium oxidation by whole cells of Nitrosomonas sp. 4 W30 grown and incubated at $5^{\circ} \mathrm{C}$

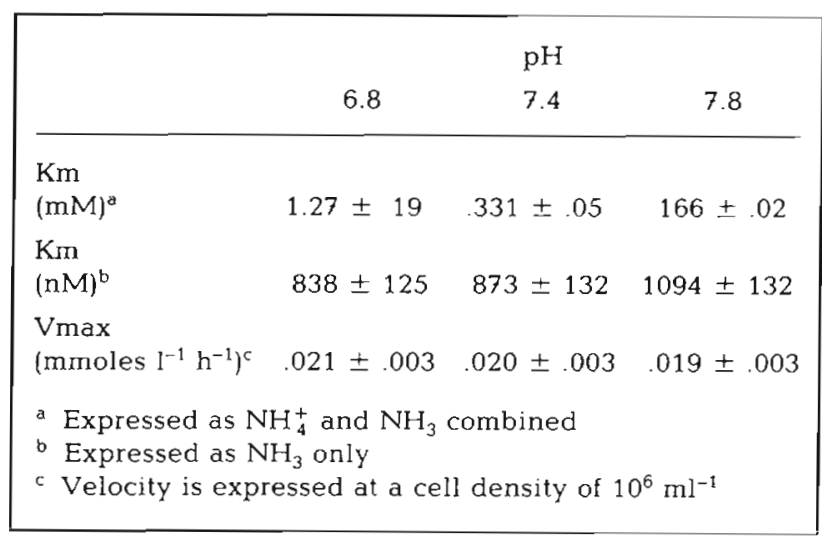

oxidation of ammonium was extremely slow even at $5^{\circ} \mathrm{C}$ unless the cells were temperature adapted. It should be pointed out, however, that since the waters from which the organism was isolated rarely exceed $14^{\circ} \mathrm{C}$ and are $<5^{\circ} \mathrm{C}$ most of the year, cells grown at $5^{\circ} \mathrm{C}$ are more likely to represent the normal cell type and the $25^{\circ} \mathrm{C}$ cells, the adapted ones.

The changes in minimum, optimum and maximum growth temperatures with cultural growth temperatures are also quite interesting. It would appear that Nitrosomonas sp. 4W30 would be quite capable of adapting to the seasonal variation in temperature found in the Alaskan waters from which it was isolated. Temperature adaptations by populations of soil nitrifying bacteria have been demonstrated by Anderson et al. (1971), but whether these were due to changes in the composition of the active assemblage of nitrifiers, or due to adaptation by the individual organisms, is unknown.

There are several possible explanations for the observed shifts in the cardinal temperatures, among these are changes in the cell membrane and the enzymatic make up of cells. Temperature has been demonstrated to alter significantly the lipid composition of the cell membranes in yeasts (Arthur and Watson, 1976). Although it is unlikely that there is a transport mechanism for ammonium oxidation, the fluidity of the membrane could significantly affect the availability of substrate at lower temperatures, and thermally induced leakage at higher temperatures could help explain the observed shifts in cardinal growth temperatures. Additional work to determine the lipid composition of both 5 and $25^{\circ} \mathrm{C}$ grown cells should help in providing an answer to this question. It is also possible that the enzymatic composition or structure of the cells could change. The whole cell kinetic studies presented in this paper do not provide an answer to these questions as there are too many additional factors that come into play when using whole cells rather than isolated enzyme systems. The similarities between the 5 and $25^{\circ} \mathrm{C}$ grown cells would seem to indicate that the enzymes responsible for ammonium oxidation to nitrite are the same but further experimentation using cell free systems are necessary to be certain of this

Cells grown at $5^{\circ} \mathrm{C}$ not only oxidized more $\mathrm{NH}_{4}^{+}$at lower temperatures on a per cell basis, as evidenced by their Vmax values (Table 1), but they also exhibited much faster generation times than would have been expected from calculations made from the growth of $25^{\circ} \mathrm{C}$ cells at $5^{\circ} \mathrm{C}$. Using $16 \mathrm{~h}$ as the mean generation time of cells grown in the $25^{\circ} \mathrm{C}$ chemostat and assuming constant $\mathrm{NO}_{2}^{-}$production for each cell division, cells growing at $5^{\circ} \mathrm{C}$ would have calculated generation times of $>560 \mathrm{~h}$. In actuality, cells in the chemostat at $5^{\circ} \mathrm{C}$ have generation times of $<60 \mathrm{~h}, 9.3$ times faster than expected

Vmax values also changed significantly with growth temperature (Table 1). This is in part due to the increased cell size (volume and dry weight) of cells grown at $5^{\circ} \mathrm{C}$ over those at $25^{\circ} \mathrm{C}$. Cells grown at $5^{\circ} \mathrm{C}$ had 1.4 times greater dry weights and therefore were likely to contain more enzyme per cell (Jones and Morita, unpubl.).

It has been suggested by Suzuki et al. (1974) that the substrate of the ammonium oxidizers may be $\mathrm{NH}_{3}$ rather than $\mathrm{NH}_{4}^{+}$. This leads to the expectation of a 
decrease in $\mathrm{Km}\left(\mathrm{NH}_{3}+\mathrm{NH}_{4}^{+}\right)$with a temperature increase, since $\left[\mathrm{NH}_{3}\right]$ would be increasing. The opposite effect was observed with both 5 and $25^{\circ} \mathrm{C}$ cells (Table 1). It is possible that $\mathrm{NH}_{3}$ is not the substrate or that temperature has an effect on the reversible formation of the enzyme-substrate complex, which seems likely. The effects of temperature on $\mathrm{Km}$ are similar to those observed by Knowles et al. (1965) for ammonium oxidation in Thames River Estuary waters, as they also found that $\mathrm{Km}$ decreased with decreasing temperature. The $\mathrm{pH}$ had the same effect on $\mathrm{Km}$ and Vmax values in these experiments as those reported by Suzuki et al. (1974) (Fig. 2 and Table 2). It was found, however, that, when $\mathrm{Km}$ values were expressed in terms of $\left[\mathrm{NH}_{3}\right], \mathrm{Km}$ values increased rather than remaining constant as reported by Suzuki et al. (1974) for Nitrosomonas europaea. These results and the temperature effects on whole cell kinetics fail to define the substrate of nitrifiers as either $\mathrm{NH}_{3}$ or $\mathrm{NH}_{4}^{+}$

The information presented in this paper demonstrates that an ammonium oxidizer isolated from a cold marine environment is capable of significant growth at low temperatures. With adaptation back to near environmental temperatures, the cardinal growth temperatures of this organism vary significantly when compared to laboratory cultures of the same organism grown at elevated temperatures.

Acknowledgements. We thank Liz Jones for the preparation of the figures used in this paper. This material is based on research supported by National Science Foundation grant OCE 84101145 . $R$. Jones was supported in part by an N. L. Tartar Research Fellowship.

\section{LITERATURE CITED}

Anderson, O. E., Boswell, F. C., Harrison, R. M. (1971). Variations in low temperature adaptability of nitrifiers in acid soils. Soil Sci. 35: 68-71

Arthur, H., Watson, K. (1976). Thermal adaptation in yeast: growth temperatures, membrane lipid, and cytochrome composition of psychrophilic, mesophilic and thermophilic yeasts. J. Bacteriol. 128: 56-68

Bendschneider, K., Robinson, R. J. (1952). A new spectrophotometric method for the determination of nitrite in sea water. J. mar. Res. 11: 87-96

Braarud, T. (1937). A quantative method for the experimental study of planktonic diatoms. J. Cons. perm. int. Explor. Mer 12: 321-332

Carlucci, A. F., Strickland, J. D. H. (1968). The isolation, purification and some kinetic studies of marine nitrifying bacteria. J. exp. mar. Biol. Ecol. 2: 156-166

Frank, H. A. (1962). Influence of low incubation temperature on classification of Pseudomonas geniculata. J. Bacteriol. 84: $68-71$

Haight, J. J., Morita, R. Y. (1966). Some physiological differences in Vibrio marinus grown at environmental and optimal temperatures. Limnol. Oceanogr. 11: 470-474

Henriksen, K., Hansen, J. I., Blackburn, T. H. (1981). Rates of nitrification, distribution of nitrifying bacteria, and nitrate fluxes in different types of sediment from Danish waters. Mar. Biol. 61: 299-304

Horrigan, S. G. (1981). Primary production under the Ross Ice Shelf, Antartica. Limnol. Oceanogr. 26: 378-382

Jones, R. D., Hood, M. A. (1980). The effects of temperature, $\mathrm{pH}$, salinity and inorganic nitrogen on the rate of ammonium oxidation by nitrifiers isolated from wetland environments. Microb. Ecol. 6: 339-347

Knowles, G., Downing, A. L., Barrett, M. J. (1965) Determination of kinetic constants for nitrifying bacteria in mixed culture, with the aid of an electronic computer. J. gen. Microbiol. 38: 263-278

Suzuki, I., Dular, U., Kwok, S. C. (1974). Ammonia or ammonium ion as substrate for oxidation by Nitrosomonas europaea cells and extracts. J. Bacteriol. 120: 556-558

Upadhyay, J., Stokes, J. L. (1962), Anaerobic growth of psychrophilic bacteria. J. Bacteriol. 83: 270-275

ZoBell, C. C. (1946). Marine microbiology. Chronica Botanica, Waltham, MA. 